\title{
TERAPI COGNITIF-BEHAVIORAL UNTUK MODIFIKASI CORE BELIEF ANTARA PASANGAN DALAM PERNIKAHAN
}

\author{
Agus Handini \\ Fakultas Tarbiyah dan Ilmu Keguruan (FTIK) \\ Institut Agama Islam Negeri (IAIN) Pontianak
}

\begin{abstract}
There are two factors causing an anxiety to women, the internal and external factors. Furthermore, the internal factor includes women's role in a domestic matter. Linda Hager says the unfinished pressure for women isto manage their schedule towards the children, society, religious life, and work's responsibility. Those, according to Hager, lead to overload or hot reactor behavior(Hager \& Hager, 1999:24). Moreover, the external factor is women's self-devotion towards their couple and children that cuts off their own time for themselves. As a result, the women will experience the loneliness, anger, and frustration because of their life choices (Hager \& Hager, 1999:24). Therefore, the honeymoon effects will be terminated due to those situation and preferences.
\end{abstract}

Keywords:

Cognitive behavioral, Core belief modification, Marride couple

\section{PENDAHULUAN}

Pasangan, baik yang menikah maupun tidak, hetero maupun homo, seringkali mengalami konflik yang membawa mereka keterapis.Seperti telah disebutkan depresi seringkali merupakan bagian gambaran klinis dari salah satu pasangan atau keduanya.

Normalitas konflik, terdapat kesepakatan yang hampir universal dikalangan terapis pasangan dan peneliti, terlepas dari orientasi teoritisnya, bahwa konflik merupakan sesuatu yang tidak dapat dihindari dalam perkawinan atau dalam berbagai hubungan jangka panjang lain. Suasana bulan madu berakhir ketika pasangan dihadapkan pada situasi yang mengharuskan mereka mengambil keputusan yang tidak romantis mengenai dimana mereka bertempat tinggal, dimana harus bekerja, bagaimana mengatur keuangan, makanan apa yang perlu disiapkan dan pembagian tanggungjawab untuk menyiapkannya,kapan harus mengunjungi mertua dan para ipar, apakah ingin memiliki anak dan kapan, dan apakah perlu bereksperimen dengan teknik seksual baru.

Dewasa ini, selain hal-hal tersebut pasangan harus menegosiasikan perubahan peran gender.Contohnya, jika keduanya bekerja, apakah tempat tinggal mereka harus disesuaikan dengan tempat kerja suami atau istri? Sumber-sumber konflik tersebut harus ditangani oleh setiap orang yang hidup bersama, terlepas dari mereka menikah atau tidak, terlepas dari mereka hetero atau homo. Otoritas sepakat bahwa cara pasangan mengatasi konflik-konflik tersebut akan menentukan kualitas dan lamanya mereka hidup bersama.

\section{CORE BELIEF PADA PASANGAN}

Suatu strategi yang dipergunakan beberapa pasangan dengan penuh pertimbangan atau tanpa disadari, adalah menolak adanya ketidaksetujuan dan konflik. Karena mereka mempercayai realitas akhir suatu kisah dongeng, "Dan mereka hidup bahagia untuk selamanya, "setiap tanda-tanda bahwa hubungan mereka tidak berjalan mulus merupakan ancaman dan harus diabaikan. Pola semacam itu dapat menjaga 
suasana damai untuk sementara waktu,namun biasanya mengakibatkan disfungsi serius dalam jangka panjang(Gottman\&Krokoff,1989).

Ketidakpuasan dan kekecewaan timbul dan mulai mempengaruhi hubungan antara keduanya seiring berjalannya waktu.Karena pasangan tersebut tidak pernah bertengkar, mereka dianggap sebagai pasangan yang sempurna oleh orang lain, namun tanpa terbukanya jalur komunikasi, mereka dapat terpisah jauh secara emosional. Berlawanan dengan itu, jika ketidaksetujuan dan bahkan ekpresi kemarahan dikaitkan dengan ketidakbahagian pada pasangan dalam jangka pendek, situasi itu sebenarnya bersifat prediktif atas kepuasan yang lebih besar seiring dengan berjalannya waktu(Gottman \& Krokoff,1989).

Dari terapi individual keterapi bersama, istilah terapi keluarga dan terapi pasangan tidak merefleksikan serangkaian prosedur.Keduanya mengindikasikan bahwa fokus terapeutik terletak pada sekurang-kurangnya dua orang dalam suatu hubungan.

Terapi pasangan dan keluarga memiliki beberapa kesamaan dalam hal kerangka kerja teoritis dengan terapi individual.Terkadang masing-masing bertemu dengan terapis yang berbeda secara terpisah, kadang-kadang secara terpisah bertemu dengan terapis yang sama, atau bersama-sama dengan terapis yang sama.

Terapi perilaku rasional emotif dari Ellis telah diterapkan dalam konflik keluarga.Sekali lagi, perspektifnya terutama individualistik atau intrapsikik. Terapis berasumsi bahwa sesuatu yang terjadi dalam diri salah satu atau kedua pasangan menyebabkan penderitaan dalam hubungan tersebut.Sang istri, contohnya dapat menyimpan keyakinan irasional bahwa suaminya harus terus menerus memujanya, bahwa pengabdiannya tidak boleh memudar.Mungkin ia kemudian akan bereaksi berlebihan ketika dalam pertemuan sosial sang suami memisahkan diri dan menikmati waktunya sendiri, bercakap-cakap dengan banyak laki-laki dan perempuan lain.

\section{KECEMASAN DALAM BERBAGAI PERSPEKTIF}

Pendekatan kognitif-behavioral, pasangan yang bermasalah tidak bereaksi satu sama lainnya secara positif, dan antagonisme tersebut biasanya dapat langsung terlihat dalam sesi pertama. Bukan sesuatu yang yang tidak biasa bahwa salah satu dari mereka dipaksa untuk menjalani terapi bersama, bahkan untuk satu sesi pertama. Dalam suatu tulisan mengenai terapi perkawinan behavioral yang menjadi pelopor merekomendasikan untuk mengatasi masalah antagonisme tersebut sebagai langkah pertama dalam membantu pasangan memperbaiki perkawinan mereka. Salah satu strategi adalah pemikiran tentang harihari kasih sayangyangdikemukakan oleh Richard Stuart, yang menggunakan strategi operant untuk konflik pasangan.Sang suami contohnya, dibujuk agar setuju untuk mengabdikan dirinya untuk melakukan hal-hal yang menyenangkan hati istrinya sepanjang hari pada satu hari tertentu, tanpa mengharapkan balasan apapun dari sang istri.Kesepakatannya adalah sang istri akan melakukan hal yang sama keesokan harinya.Jika berhasil, strategi ini dapat mencapai sekurang-kurangnya dua tujuan penting, pertama menghancurkan lingkaran jarak, kecurigaan dan kontrol yang tidak menyenangkan antara satu sama lainnya dan kedua, menunjukkan kepada mereka bahwa melakukan hal-hal yang menyenangkan pasangan mereka dapat memberikan pengaruh positif kepada masing-masing.Hal ini meningkatkan perasaan bahwa kontrol positif dapat dicapai hanya dengan cara menyenangkan pasangan.Perbaikan suasana yang dihasilkan oleh apa yang dilakukan masing-masing pasangan untuk secara timbal balik saling menyenangkan hati membantu mereka termotivasi untuk menyenangkan pasangan dalam berbagai hal pada masa mendatang.

Georgia Witkin seorang konselor wanita mengungkapkan bahwa kecemasan yang dialami wanita dapat berkaitan dengan perkembangan fisiknya, perubahan peran dan dengan psikologisnya (Right, 1993:53).

Perubahan peran wanita ini menimbulkan beberapa tekanan sebagai akibat dari keputusan suami bahwa istri memasuki lapangan kerja namun tetap memelihara hubungan mereka sebagai suami istri (G. Wade dan Mary Jo Rowatt, 1994:5). Tekanan yang bersifat eksternal disebabkan oleh lingkungan masyarakat. Walaupun istri tidak memiliki pekerjaan di luar rumah, tekanan yang ditimbulkan oleh masyarakat dapat menimbulkan stres berat seperti birokrasi, mode dan emansipasi (Coleman, 1988:5-9). 
Menurut publikasi Komnas Perempuan, bangsa Indonesia telah mengenal bentuk-bentuk tindak kekerasan terhadap perempuan, seperti kawin paksa, poligami, perceraian secara sepihak tanpa mempertimbangkan keadilan bagi isteri dan anak, tindak pemukulan dan penganiayaan, dan bentuk-bentuk kesewenangan lain terhadap perempuan, merupakan contoh yang tidak sulit untuk ditemukan pada masyarakat Indonesia (2002:22). Kekerasan yang dialami oleh perempuan ini sangat banyak bentuknya, baik yang bersifat psikologis, fisik, seksual, ekonomis, budaya dan keagamaan, hingga bagian dari sebuah sistem pengorganisasian lintas negara.

Menurut Post (1978:57-86), kecemasan adalah kondisi emosional yang tidak menyenangkan, yang ditandai oleh perasaan-perasaan subjektif seperti ketegangan, ketakutan, kekhawatiran dan juga ditandai dengan aktifnya sistem syaraf pusat. Freud (dalam Arndt, 1974:78) menggambarkan dan mendefinisikan kecemasan sebagai suatu perasaan yang tidak menyenangkan, yang diikuti oleh reaksi fisiologis tertentu seperti perubahan detak jantung dan pernafasan.

Kartono (1981:113) juga mengungkapkan bahwa neurosa kecemasan pada wanita ialah kondisi psikis dalam ketakutan dan kecemasan yang kronis, sungguhpun tidak ada rangsangan yang spesifik. Menurutnya, kecemasan ditandai dengan emosi yang tidak stabil, mudah tersinggung dan marah, sering dalam keadaan gelisah.Menurut Wignyosoebroto (1981:45), ada perbedaan mendasar antara kecemasan dan ketakutan. Pada ketakutan, apa yang menjadi sumber penyebabnya selalu dapat ditunjuk secara nyata. Sedangkan pada kecemasan sumber penyebabnya tidak dapat ditunjuk dengan tegas, jelas dan tepat.

Jersild (1960:28) menyatakan bahwa ada dua tingkatan kecemasan. Pertama, kecemasannormal, yaitu pada saat individu masih menyadari konflik-konflik dalam diri yang menyebabkan cemas. Kedua, kecemasanneurotik, ketika individu tidak menyadari adanya konflik dan tidak mengetahui penyebab cemas, kecemasan kemudian dapat menjadi bentuk pertahanan diri. Menurut Bucklew (1980:145), para ahli membagi bentuk kecemasan pada wanita dalam dua tingkat, yaitu:

1. Tingkat psikologis. Kecemasan yang berwujud sebagai gejala-gejala kejiwaan, seperti tegang, bingung, khawatir, sukar berkonsentrasi, perasaan tidak menentu dan sebagainya.

2. Tingkat fisiologis. Kecemasan yang sudah mempengaruhi atau terwujud pada gejala-gejala fisik, terutama pada fungsi sistem syaraf, misalnya tidak dapat tidur, jantung berdebardebar, gemetar, perut mual, dan sebagainya.

Simtom-simtom somatis yang dapat menunjukkan ciri-ciri kecemasan menurut Stern (1964) adalah muntah-muntah, diare, denyut jantung yang bertambah keras, seringkali buang air, nafas sesak disertai ketegangan pada otot-otot. Sue, dkk (dalam Kartikasari, 1995:79) menyebutkan bahwa manifestasi kecemasan terwujud dalam empat hal berikut ini.

1. Manifestasi kognitif, yang terwujud dalam pikiran seseorang, seringkali memikirkan tentang malapetaka atau kejadian buruk yang akan terjadi.

2. Perilaku motorik, kecemasan seseorang terwujud dalam gerakan tidak menentu seperti gemetar.

3. Perubahan somatik, muncul dalam keadaaan mulut kering, tangan dan kaki dingin, diare, sering kencing, ketegangan otot, peningkatan tekanan darah dan lain-lain. Hampir semua penderita kecemasan menunjukkan peningkatan detak jantung, respirasi, ketegangan otot dan tekanan darah.

Menurut Horney (dalam Arndt, 1974:6-9), sumber-sumber ancaman yang dapat menimbulkan kecemasan pada wanita dapat bersifat lebih umum. Penyebab kecemasan menurut Horney, dapat berasal dari berbagai kejadian di dalam kehidupan atau dapat terletak di dalam diri seseorang. Suatu kekaburan atau ketidakjelasan, ketakutan akan dipisahkan dari sumbersumber pemenuhan kekuasaan dan kesamaan dengan orang lain adalah penyebab terjadinya kecemasan dalam konsep kecemasan Angyal (1974:38).

Murray (dalam Arndt 1974:17-19) sumber-sumber kecemasan adalah keinginankeinginanuntuk menghindar dari terluka (harmavoidance), menghindari teracuni (infavoidance), menghindar dari disalahkan (blamavoidance) dan bermacam sumber-sumber lain. Disamping 
ketiga keinginan tersebut ia juga menyebutkan bahwa kecemasan wanita dapat merupakan reaksi emosional pada berbagai kekhawatiran, seperti kekhawatiran pada masalah sekolah, masalah finansial, kehilangan objek yang dicintai dan sebagainya.

Faktor kepribadian yang berpengaruh pada kecemasan adalah kepercayaan diri dan motivasi presentasi diri (dalam Hidayat dkk, 1996:25). Saat individu menghadapi keadaan yang dianggapnya mengancam, maka secara umum ia akan memiliki reaksi yang biasanya berupa rasa takut. Kebingungan menghadapi stimulus yang berlebihan yang tidak berhasil dikendalikan oleh ego, maka ego akan diliputi kecemasan.Kecemasan sebagai tanda peringatan bagi individu bahwa ia dalam bahaya, merupakan isyarat bagi ego untuk melakukan tindakan-tindakan yang tepat (Freud dalam Hall \& Lindzey, 1993). Kecemasan adalah suatu keadaan tegangan dan merupakan suatu dorongan yang timbul oleh sebab dari luar (Freud dalam Hall \& Lindzey, 1993:35). Atau dari pendapat lain Maramis (dalam Anima Psikologi Indonesia, 1994:26) mengemukakan kecemasan adalah suatu ketegangan, rasa tidak aman, kekhawatiran yang timbul karena dirasakan akan mengalami kejadian yang tidak menyenangkan.

Kecemasan merupakan salah satu unsur emosi yang pernah dialami oleh seorang wanita di dalam kehidupannya, karena suatu pengalaman baru yang dijumpai dalam kehidupan ini tidak selalu menyenangkan, tetapi ada kalanya muncul situasi yang membawa kecemasan. Penyebab timbulnya kecemasan pada wanita sukar diperkirakan dengan tepat. Hal ini disebabkan oleh adanya sifat subjektif dari kecemasan, yaitu bahwa kejadian atau pengalaman seorang wanita yang sama belum tentu dirasakan sama pula oleh wanita lain, dengan kata lain suatu rangsang atau kejadian dengan kualitas dan kuantitas yang sama dapat diinterpretasikan secara berbeda antara wanita yang satu dengan wanita yang lainnya.

Kecemasan merupakan pengalaman subjektif yang tidak menyenangkan yang berbentuk ketegangan, kegelisahan, tertekan, yang disertai dengan gejala-gejala fisiologis, misalnya sakit kepala, nyeri pada pinggang, sesak nafas, sakit perut, mual, dan lain-lain (Philip \& Solomon dalam Anima Psikologi Indonesia, 1994:243).

Lazarus (dalam Blackburn \& Davidson, 1994:21) dengan model kecemasannya yang benar-benar berorientasi kognitif, membuat suatu pembedaan antara proses penilaian primer dan sekunder. Penilaian primer adalah penilaian seseorang wanita yang menganggap bahwa suatu situasi sebagai sesuatu yang mengancam. Hal ini berhubungan dengan ancaman yang dilakukan oleh suami kepada istrinya.

Sedangkan penilaian sekunder terdiri dari penilaian apakah ia mempunyai sumbersumber internal dan eksternal yang diperlukan untuk menghadapi situasi tersebut. Kombinasi kedua penilaian tersebut, yaitu adanya ancaman yang potensial (primer) dan penguasaan sumber-sumber (sekunder), menentukan tingkat kecemasan yang dialami seseorang pada situasi tertentu. Tetapi dari faktor kepribadian seorang wanita yang berpengaruh langsung pada kecemasan adalah kepercayaan diri dan motivasi presentasi diri.

Tetapi beberapa penelitian dari para ahli tentang studi kecemasan secara umum, menyatakan bahwa perempuan lebih cemas daripada laki-laki (Maccoby dan Jacklin, 1974:56). Myers (1983:36) mengatakan bahwa wanita lebih cemas akan ketidakmampuannya dibanding dengan laki-laki, laki-laki lebih aktif, eksploratif, sedangkan wanita lebih sensitif.

Hasil penelitian lain (dalam Leary, 1982:76) menyatakan bahwa wanita memiliki skor yang lebih tinggi pada pengukuran ketakutan dalam situasi sosial dibanding pria. James (dalam Smith, 1968:51) mengatakan bahwa perempuan lebih mudah dipengaruhi oleh tekanan-tekanan lingkungan daripada laki-laki. Perempuan juga lebih cemas, kurang sabar, dan mudah mengeluarkan air mata (Cattel, dalam Smith, 1968:24). Lebih jauh lagi, Morris (dalam Leary, 1982:81) menyatakan bahwa perempuan memiliki skor yang lebih tinggi pada pengukuran ketakutan dalam situasi sosial dibanding laki-laki.

Seseorang yang mengalami kecemasan dalam berbagai bentuk, sebenarnya berada dalam kondisi emosi yang sama sekali tidak menyenangkan (Spielberger, dalam Post dkk.,1978:65). 
Lazarus, (1976:90) menjelaskan lebih lanjut bahwa perasaan cemas sebenarnya merupakan pengalaman yang samar-samar disertai dengan adanya perasaan tidak berdaya.

Selain itu kecemasan pada wanita dapat dipengaruhi oleh mood seseorang. Ada dua mekanisme di mana mood mempengaruhi memori seorang wanita. (1) Mood-dependent memory, suatu informasi atau realita yang menimbulkan mood tertentu, atau (2) Mood congruence effects, kecenderungan untuk menyimpan atau mengingat informasi positif kala mood sedang baik, dan sebaliknya informasi negatif lebih tertangkap atau diingat ketika mood sedang jelek (Byrne \& Baron, 2000:16).

\section{KOGNITIF DALAM MODEL PEMAHAMAN KECEMASAN}

Seorang wanita dapat mengalami kecemasan karena pengaruh pikirannya. Laugesen (2003:30) dalam studinya tentang empat model kognitif yang digagas oleh Dugas, Gagnon, Ladouceur dan Freeston (1998:24) menemukan bahwa empat model kognitif tersebut efektif bagi pencegahan dan perlakuan terhadap kecemasan. Kecemasan merupakan fenomena kognitif, fokus pada hasil negatif dan ketidakjelasan hasil di depan. Hal ini didasari dari definisi Vasey \& Daleiden (dalam Laugesen, 2003:192) berikut; Empat model kognitif itu ialah (1) tidak toleran (intoleransi) terhadap ketidakpastian, (2) keyakinan positif tentang kecemasan, (3) orientasi negatif terhadap masalah, serta (4) penghindaran kognitif.

Pemahaman tiap variabel tersebut; (1) intoleransi terhadap ketidakpastian merupakan bias kognitif yang mempengaruhi bagaimana seseorang menerima, menginterpretasi dan merespons ketidakpastian situasi pada tataran kognitif, emosi dan perilaku; misalnya wanita yang memandang suaminya tidak stabil emosinya, atau wanita yang mengalami kecemasan ekonomi. Ia melihat suaminya malas bekerja sedangkan kebutuhan hidup meningkat dengan bertambahnya usia anak dan biaya pendidikan anak; (2) sejumlah studi menunjukkan bahwa wanita yang meyakini bahwa perasaan cemas dapat membimbing pada hasil positif seperti solusi yang lebih baik dari masalah, meningkatkan motivasi atau mencegah dan meminimalisir hasil negatif, dapat membantu mereka dalam menghadapi ketakutan dan kegelisahan wanita yang memiliki komunitas positif akan lebih mudah mendapat pengaruh yang positif; (3) orientasi negatif terhadap masalah merupakan seperangkat kognitif negatif yang meliputi kecenderungan untuk menganggap masalah sebagai ancaman, memandangnya sebagai sesuatu yang tidak dapat dipecahkan, meragukan kemampuan diri dalam menyelesaikan masalah, menjadi merasa frustrasi dan sangat terganggu ketika masalah muncul; (4) penghindaran kognitif dikonsepsikan dalam dua cara, yakni (a) proses otomatis dalam menghindari bayangan mental yang mengancam dan (b) strategi untuk menekan pikiran-pikiran yang tidak diinginkan.

\section{BELIEFS (KEYAKINAN)}

Apa yang kita terima dari kecil dan berkembang sampai kita dewasa, terbangun menjadi keyakinan kita, dan kita percaya sebagai hal yang benar.Adapun keyakinan- keyakinan inti (corebeliefs) merupakan pengertian-pengertian yang sangat fundamental dan mendalam (deep) dari diri yang sering tidak diartikulasikan, bahkan terhadap diri sendiri. Dianggap sebagai kebenaran yang absolut.Core-beliefs (CB) merupakantingkat keyakinan yang paling mendasar (fundamental), sifatnya global, kaku, dan over generalized (menyama ratakan).CBT didasari pada Model Kognitif dari respon emosional.

Didasari pada fakta ilmiah yang menunjukan bahwa pikiran kita menimbulkan perasaan dan perilaku,bukan faktor eksternal.Keuntungannya adalah kita dapat mengubah cara kita berpikir agar merasakan dan bertindak lebih baik meskipun suasananya tidak berubah. Yang sangat penting bagi terapis kognitif dalah keyakinan yang tidak rasional (disfunctional) dapat di ajarkan kembali (unlearned), dimana keyakinan baru yang lebih realistis yang berdasarkan keberfungsian dapat dikembangkan dan dipelajari melalui proses terapi. 


\section{Model Kognitif}

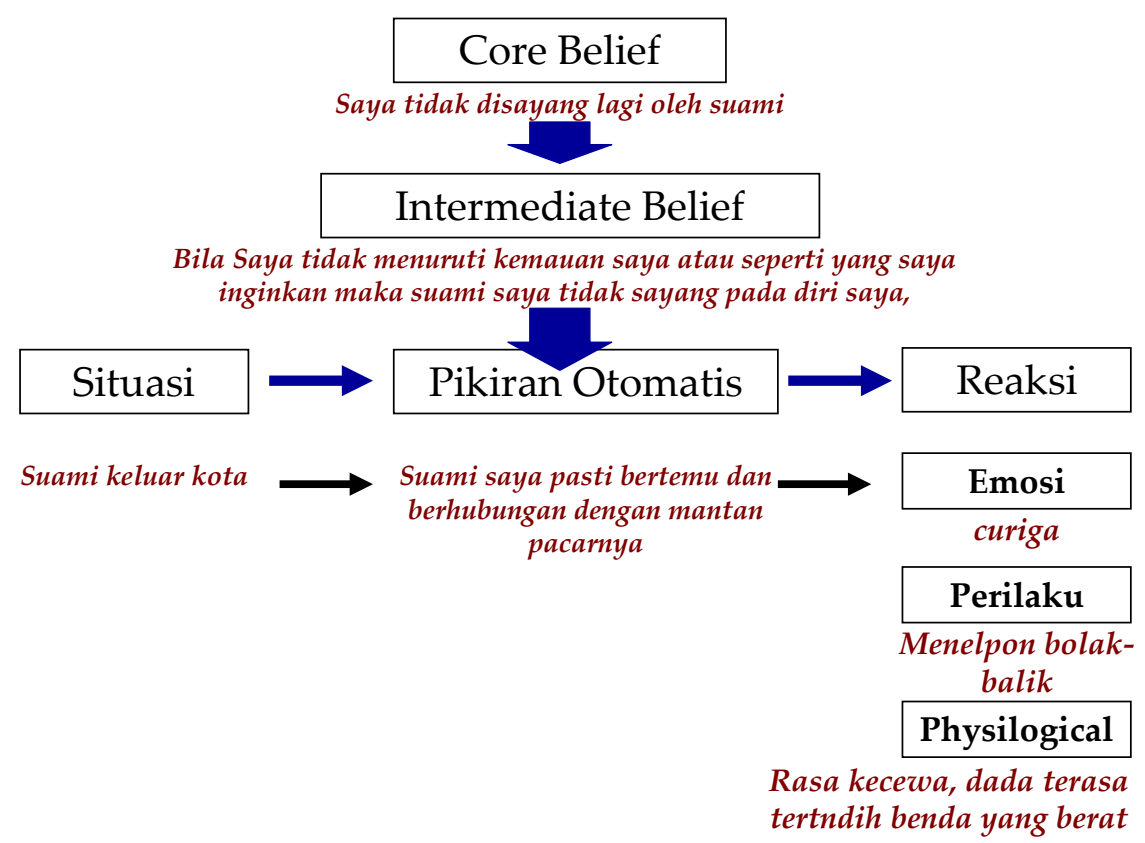

Perhatian terakhir ditujukan pada efisiensi terapi menjadi 5 (lima) sesi diharapkan dapat memberikan bayangan yang lebih jelas mengundang kreativitas yang lebih tinggi.untuk dilanjutkan pada sessi berikutnya.

Adapun pembagian sesi tersebut adalah :

Sessi 1: Asesmen dan diagnosa awal, dengan tujuan

1. Melakukan assesmen,observasi,anamnesa, dan analisa gejala,demi menegakkan diagnosa awal mengenai ganguan yang terjadi.

2. Memberikan dukungan dan semangat kepada klien untuk melakukan perubahan

3. Memperoleh komitmen dari klien untuk melakukan terapi dan pemecahan masalah terhadap gangguan yang dialami

4. Menjelaskan kepada klien formulasi masalah dan situasi kondisi yang dihadapi

Sessi 2: Mencari emosi negatif,pikiran otomatis dan keyakinan utama yang berhubungan dengan gangguan dengan tujuan:

1. Memberikan bukti bagaimana sistem keyakinan dan pikiran otomatis sangat erat hubungannya dengan emosi dan tingkahlaku, dengan cara menolak pikiran negatif secara halus dan menawarkan pikiran positif sebagai alternatif untuk dibuktikan bersama.

2. Memperoleh komitmen klien untuk melakukan modifikasi secara menyeluruh, mulai dari pikiran,perasaan sampai perbuatan dari negatif menjadi positif.

Sessi 3: Menyusun rencana intervensi dengan memberikan konsekuensi positif konsekuensi negatif kepada klien dan kepada "significant persons"

Sessi 4: Formulasi status,fokus terapi,intervensi tingkahlaku lanjutan, dengan tujuan memberikan

1. Dukungan dan semangat kepada kemajuan yang dicapai klien

2. Keyakinan untuk tetap fokus kepada masalah utama

Sessi 5: Pencegahan Relapse 
1. Komitmen klien untuk melanjutkan terapi dalam sessi yang lebih jarang dan melakukan metode "self help" secara berkesinambungan.

2. Komitmen klien untuk secara aktif membentuk pikiran-perasaan-perbuatan positif dalam setiap masalah yang dihadapi.

Perlu dilakukan metode pencatatan arsip klien yang seksama, walaupun dalam prakteknya akan menemukan kesulitan antara pelaksanaan proses terapi dan pencatatan dalam waktu bersamaan, namun tetap dianjurkan untuk selalu membuat catatan-catatan tentang proses terapi dan perkembangan klien, sesuai dengan kejadian yang muncul selama sessi terapi berlangsung. Dengan catatan yang bertanggung jawab,proses terapi menjadi lebih mudah Dalam semua terapi pasangan masing-masing pasangan dilatih untuk mendengarkan pasangannya dengan empati dan untuk menyatakan dengan jelas kepada pasangannya agar mengatakan apa yang dipahaminya dan perasaan yang ada dibalik ucapan tersebut. Salah satu cara memperbaiki komunikasi adalah dengan membedakan antara maksud kata-kata tersebut dengan dampaknya.

Penelitian menunjukkan bahwa komunikasi pasangan yang bermasalah dan pasangan yang berbahagia mungkin tidak jauh berbeda dengan maksudnya namun, tidak dalam dampaknya.Suatu pola interaksi yang disebut siklus tuntutan penarikan diri secara luas dianggap destruktif bagi pasangan.Pola tuntutan -penarikan diri ditandai dengan upaya salah satu pasangan untuk membahas suatu masalah, dan yang lain menghindar atau menarik diri dari upaya semacam itu.Penarikan diri semacam itu menimbulkan tuntutan dari pasangan yang pertama yang kemudian berusaha lebih keras lagi untuk melibatkan yang lain, namun justru mendapatkan penolakkan yang lebih besar. Demikianlah siklus tersebut semakin kuat. Christensen dan Heavey (1990) berpendapat bahwa terdapat perbedaan gender dalam pola ini, perempuan cenderung berada pada posisi menuntut, sedangkan laki-laki biasanya menarik diri.

Suatu praktik umum dikalangan terapis keluarga adalah memberikan tugas-tugas rumah yang spesifik kepada pasangan untuk melatih berbagai pola interaksi baru yang telah mereka pelajari didalam sesi dan memulai proses penting,untuk mengeneralisasi perubahan dari ruang konsultasi kedalam kehidupan sehari-hari.

\section{PENUTUP}

Dalam pelaksanaan praktek terapi cognitive behavior memerlukan penyesuaian yang lebih fleksibel dengan mempertimbangkan hal pertama dengan adanya kebutuhan partisipasi dan pengertian yang lebih besar kepada klien, proses terapi cognitif behavior memerlukan keterlibatan yang besar dari terapis, dengan dasar pemikiran bahwa klien yang datang untuk terapi sudah memiliki keinginan untuk melakukan perubahan namun tidak mampu melakukannya sendiri,terapis harus lebih siap dalam mengajarkan keterampilan dan teknik yang aplikatif untuk mendengar efektif, observasi terhadap kemajuan, dan memahami masalah yang sebenarnya bukan sekedar masalah dipermukaan saja. Terapis dan klien perlu bersama-sama menguraikan masalah dan memperoleh pehaman yang lebih jelas tentang gangguan yang dialami.Perhatian terhadap seluruh kemungkinan tanda-tanda perilaku perlu dilakukan,antara lain terhadap:pikiran yang disadari, pikiran yang tidak disadari, masa lalu, pola asuh keluarga, kualitas hubungan, karakteristik gejala gangguan, konflik, luapan emosi.

Perhatian kedua ditujukan kepada penjelajahan yang mendalam terhadap pikiran,emosi dan tingkah laku,karena kita menyadari bahwa jaringan SKR (stimulus kognisi respons) dalam diri klien telah membentuk semacam selaput gelap yang mempengaruhi ekspresi emosi dan perilakunya, proses terapi harus benar-benar menembus keyakinan negatif klien secar menyeluruh. Terapis harus berupaya mengekplorasi setiap pikiran otomatis, ekspresi emosi dan tingkahlaku yang berhubungan dengan gangguan, untuk diperbandingkan dengan norma masyarakat yang berlaku dan kehidupan nyata. Dengan kata lain pikiran negatif mutlak ditemukan/diidentifikasi agar dapat dimodifikasi menjadi pikiran yang lebih positif.Dalam hal ini unsur budaya dan aliran kepercayaan 
klien kerap menjadi faktor yang mempengaruhi dalam mepberikan penilaian apakah suatu pikiran dapat dipertimbangkan sebagai negatif.

Perhatian ketiga ditujukan pada teknik memperbaiki pola pemikiran yang negatif, disini terapis harus mencoba untuk memberi semangat klien dalam mencari pemikiran-pemikiran yang lebih positif dan rasional.Pertanyaan-pertanyaan seperti,apa?mengapa tidak? mengapa harus demikian?", perlu diperkaya dengan pertanyaan-pertanyaan seperti mengapa tidak seperti ini?Maukah Anda mencoba untuk berangkat dari pemikiran yang berbeda misalnya....?. Terapis diharapkan dapat memberikan dukungan kepada klien untuk tertarik agar membentuk pola pemikiran yang berbeda.Penolakan atau penyerangan terhadap pola pemikiran negatifnya dan bukan kepada pribadi klien.Studi komparatif terhadap klien yang telah berhasil mengatasi gangguan, dapat menjadi salah satu cara untuk menumbuhkan semangat klien. Perhatian yang keempat adalah teknik kombinasi berbagai metode dan model belajar kreatif, disini terapis harus mampu bersikap kreatif dalam merencanakan metode dan model belajar yang akan diterapkan kepada klien, antara lain:Diskusi yang menghasilkan kesimpulan dan pengambilan keputusan, teknik direktif/mengarahkan klien dalam melakukan pola berfikir yang berbeda, teknik berbicara kepada diri sendiri, mengundang inspirasi klien, visualisasi masalah dengan gambar,film,internet dan lain-lain, relaksasi dan hypnosis, eksperimen, dan bentuk-bentuk experiential learning lainnya.

Perhatian yang kelima yaitu lebih sensitif terhadap kebutuhan klien, disiniterapis perlu bersikap lebih fleksibel dalam menampilkan "kekuatannya".Sikap direktif yang kaku justru membuat klien tidak nyaman dan tidak datang lagi pada sesi berikutnya.Sementara itu terapis harus tetap mampu mengendalikan proses terapi tanpa mengabaikan kebutuhan klien.Klien harus dibuat sedemikian rupa tertarik dan mau mempercayai pola pemikiran baru yang posetif dan rasional tanpa merasa terpaksa.Apabila belum memungkinkan untuk dilakukan, berilah tambahan waktu.Sebagian klien mungkin memerlukan perhatian terapis untuk dapat menumpahkan emosinya terlebih dahulu sebelum memulai proses terapi cognitif behavior.Sebaliknya terapis wajib bersikap jujur pula apabila ternyata klien sebenarnya memang tidak memerlukan terapi.Perhatian yang keenam adalah memberikan bantuan dan intervensi terhadap ingatan masa lalu dengan bypnosis, sejalan dengan cognitif behavior modification yang menggunakan relaksasi dalam menrektrukturisasi distorsi kognitifnya, klien memerlukan keterampilan praktis untuk merekam ulang pikiran-pikiran negatif untuk menjadi pikiran-pikiran positif.Klien diharapkan mampu belajar untuk mengingat masalalunya secara lebih positif yang memerlukan bantuan dan intervensi dari terapis.Berdasarkan pengalaman,umumnya klien selalu memerlukan penguatan untuk dapat melakukan modifikasi terhadap ingatannya tentang masa lalu.Perhatian yang ketujuh adalah bantuan dan dukungan bahwa pola pikir yang baru dapat meberikan kehidupan dan fungsi pribadi yang lebih baik.Disamping konsekuensi positif dan negatif (reward dan punishment) yang diterapkan kepada klien untuk mendukung proses belajar klien,terapis perlu memberikan dukungan semangat yang lebih banyak lagi demi membuktikan bahwa proses terapi akan memberikan hasil yang efektif dalam mengatsi gangguan.Terapis dapat memilih teknik dukungan yang kreatif,misalnya langsung menyediakan bukti-bukti yang mendukung keberhasilan terapi, siap dengan cerita-cerita tentang keberhasilan,sedikit waktu dan tenaga ekstra, baik didalam maupun diluar waktu konseling hanya untuk memantapkan klien.Klien diyakinkan bahwa ia akan memiliki kehidupan dan fungsi pribadi yang lebih baik dalam waktu yang singkatsetelah ia berhasil merektrurisasikan cara pandang,perasaan dan perbuatannya. ***

\section{REFERENSI}

APA, 1996. Dianostik. And Statistical Manual Of Mental Disorde.,Fourth Edition.DSM-IV-TR.John Wiley \& Sons,Inc.

Beck,S. Judith, 1995. Cognitive Therapy.The Guilford Press, .New York. 
Davidson, Corey Gerald, 1986. Teori Dan Praktek Konseling dan Psikoterapi. Brooks/Cole Publishing Company Pacific Grove California.

Davidson, D.G., Naele, J.M.\& Kring,A.M, 2004. Abnormal Psychology (9thed). New York : John Wiley \& Sons

Edelmann, R.J., 1992. Anxiety Theory.Research and Intervention in Clinical and health Psychological.Chichester: John Wiley \& Sons

Freeman, Arthur., 2005. Encyclopedia of Cognitive Behavior Therapy. Springer Science and Business Media, Inc.

Gerald, 2004.Psikologi Abnormal. PT. RajaGrafindo. Jakarta.

George Rickey L,Cristiani Therese S.Counseling Theory and Practice. Third Edition.Prentice Hall. Englewood CliffsNew Jersey 07632.

Iskandar Y., 1994. Mengatasi Anxietas, Yayasan Dharma Graha.

Kaplan Harold I,MD.,Sadock Benjamin J,MD.,Grebb Jack A,Md., 1997.Sinopsis Psikiatri, Jilid Dua.Binarupa Aksara.

Monintja, Jesse.A. Modules \& Reading Materials : Pelatihan Perilaku Rasional, Teori \& Aplikasi CognitiveBehavioral Therapy, Terapi Kognitif untuk mengendalikan Respons

Emosi, 14-15 Juni 2008, Hotel Santika, Bandung

Milkman, Harvey., Wanberg Kennet. 2007. Cognitive Behavioral Treatment. Nation Institute of Correction. Washington DC.

Oemarjoedi, A. Kasandra, 2003. Pendekatan Cognitive Behavior danPsikoterapi.Creativ Media. Jakarta

Wiramihardja Sutardjo A,Prof.,2005. Pengantar Psikologi Abnormal.Refika Aditama Bandung. 